\title{
Obywatelska inicjatywa uchwałodawcza jako element partycypacji obywatelskiej w kontekście kondycji polskiej samorządności lokalnej na poziomie gmin
}

\section{Wprowadzenie}

Niniejsze opracowanie umiejscowić należy w gałęzi nauk prawnych zwanej socjologią prawa. Obejmuje ona wiele aspektów z pogranicza nauk prawnych, społecznych oraz humanistycznych. Podstawową klasyfikację problemów badawczych w tej materii sporządził A. Kojder, który zalicza do nich: prawo jako porządek społeczny oraz jego relacje z innymi porządkami, prawo $\mathrm{w}$ aspekcie organizacyjnym, sztab prawny oraz jego działania, a także szeroko rozumiane relacje między prawem a życiem społecznym, ze szczególnym uwzględnieniem funkcji regulacyjnej prawa w społeczeństwie ${ }^{1}$. Artykuł ten dotyczy właśnie relacji między prawem a życiem społecznym - między prawną formą partycypacji, jaką jest obywatelska inicjatywa uchwałodawcza, a współczesną polską gmina, ze wszystkimi jej problemami na gruncie samorządności lokalnej. Dlatego też w tekście tym nie użyto zarezerwowanych dla nauk prawnych metod badawczych. Oczywiście, w lekturze tego opracowania należy mieć na względzie, że obywatelska inicjatywa uchwałodawcza jest urzeczywistnieniem fazy inicjatorskiej tworzenia aktów prawa miejscowego. Znaczenie tej fazy jest ważne, gdyż liczba podmiotów w niej uczestniczących ma bardzo duże znaczenie z punktu widzenia udziału obywateli w rządzeniu państwem oraz ich wpływu na działalność organów

\footnotetext{
${ }^{1}$ A. Kojder, Godność i siła prawa, Warszawa 2001, s. 202-204.
} 
państwowych ${ }^{2}$. Jest to bardzo istotne z punktu widzenia prawodawstwa, ponieważ przy wyznaczaniu granic regulacji prawnej kryteria społeczne odgrywają co najmniej równie ważną rolę jak inne. Prawo jest bowiem uznawane za system norm zakorzenionych w społecznym systemie wartości. Nie jest wyznacznikiem, lecz formą wyrażania wolności i innych wartości obywatelskich ${ }^{3}$. Prawodawca w procesie prawodawstwa często nie stanowi, ale uznaje daną normę. Dzieje się tak, gdy przez dłuższy czas pozaprawna norma postępowania funkcjonuje w społeczeństwie, w którym wykształciło się przekonanie, że istnieje potrzeba prawnej gwarancji tej normy ${ }^{4}$. Pamiętać wreszcie należy, że prawo jest tylko jedną z form warunkujących życie społeczne oraz zachowania ludzi. Do pozostałych zalicza się normy: moralne, organizacyjne, techniczne, a także estetyczne. Prawo jako jeden z czynników może pozostawać z pozostałymi w różnych relacjach oraz niekoniecznie zgodnych i uzupełniających się relacjach ${ }^{5}$. Dlatego też badania nad tworzeniem prawa miejscowego, jako jedną z form regulacji życia i zachowania obywateli, muszą nastąpić na podstawach socjologiczno-prawnych osadzonych w badaniach nad społeczeństwem lokalnym w gminie jako podstawowej jednostce samorządu terytorialnego w Polsce.

Teoretyczno- i socjologiczno-prawne podejście do konkretnego mechanizmu partycypacji obywatelskiej pozwala zrozumieć, jakie aspekty społeczne leżą u podstaw omawianej obywatelskiej inicjatywy uchwałodawczej. Krótkiej syntezie w artykule poddano podmiot, który jednocześnie jest jednostkowy i zatomizowany, ale także osadzony w pewnej większej całości, w obrębie której realizuje swoją podmiotowość. Rozwój jednostkowego podmiotu odbywa się więc wewnątrz bytu zbiorowego, w którym następuje koordynacja działań członków na rzecz tak zwanego dobra wspólnego. Dobro wspólne dotyczy zatem z jednej strony skoordynowania działań jednostek, z drugiej zaś warunków niezbędnych do indywidualnego rozwoju członków grupy ${ }^{6}$.

W tym ujęciu obywatelska inicjatywa uchwałodawcza rozumiana jest właśnie jako dobro wspólne. Po pierwsze, sprzyja rozwojowi

${ }^{2}$ H. Rot, Wartości proceduralne tworzenia prawa. Studium legislacji porównawczej, Wrocław 1992, s. 34.

${ }^{3}$ Ibidem, s. 17.

${ }^{4}$ A. Redelbach, Wstęp do prawoznawstwa, Poznań 1996, s. 109-110.

${ }^{5}$ H. Rot, Wstęp do nauk prawnych, Wrocław 1994, s. 18-26.

${ }^{6}$ P. Łabieniec, Prawo rozumu. O teorii prawa naturalnego Johna Finnisa, Łódź 2004, s. 36-37. 
podmiotowemu członków społeczności lokalnych, po drugie, spaja grupę w dążeniu do wspólnego celu, a po trzecie, stanowi prawny mechanizm koordynujący działania na rzecz danej inicjatywy. Dalsze części artykułu wyjaśniają, czym jest obywatelska inicjatywa uchwałodawcza, co to znaczy „być podmiotem inicjującym”, jak owe podmiotowe jednostki osadzone są w większych grupach lokalnych społeczności.

Niniejsze opracowanie jest wstępem do badań nad obywatelską inicjatywą uchwałodawcza, jest próbą znalezienia jej podstaw w warunkach społecznych. Omawiany socjologiczno-prawny wstęp do badań normatywnych porusza więc wiele aspektów. Podstawy społeczne funkcjonowania partycypacji obywatelskiej w Polsce na poziomie gminy nie są dziś łatwe do znalezienia. Polska ma bowiem stosunkowo krótkie tradycje samorządowe. Prowadzone przez autora badania nad obywatelską inicjatywą uchwałodawczą zbiegają się z 25 . rocznica wprowadzenia w Polsce ustroju demokratycznego. Jednym z aspektów demokratyzacji naszego kraju była decentralizacja. Została ona wyrażona $w$ dwóch reformach samorządowych wdrożonych w latach 1990 i 1998. W dzisiejszym kształcie samorzą $\mathrm{z}$ drobnymi zmianami ewolucyjnymi trwa od dziewiętnastu lat, a samorząd gmin de facto od ćwierćwiecza. Od blisko 25 lat Polacy mogą cieszyć się prawem do podejmowania samodzielnych decyzji w swoich gminach. Jest to więc bardzo dobry czas, aby poczynić podsumowanie samorządności lokalnej w Polsce. Na przykładzie obywatelskiej inicjatywy uchwałodawczej ukazać można nie tylko stan demokracji lokalnej na poziomie polskich gmin, ale również kondycję ich uwspólnotowienia, które jest sprzężone $z$ demokracją. Właściwy poziom poczucia wspólnoty wpływa na prawidłowość procesów demokratycznych i obywatelskich, a te z kolei wzmacnia wspólnotowość. Obywatelska inicjatywa uchwałodawcza jest tu swego rodzaju kluczem. Stanowi ona bowiem bardzo ważny element nowoczesnej, zaangażowanej demokracji bezpośredniej, będący urzeczywistnieniem podmiotowego sprawstwa obywatela. Ponadto ukazuje całokształt demokracji rozumianej nie tylko jako realizacja woli większości, ale przede wszystkim jako podmiotowy udział obywateli w sprawowaniu władzy poprzez mechanizmy partycypacji oraz demokracji bezpośredniej. Podczas prowadzenia badań należy jednak uwzględnić pewne zagrożenia wynikające $\mathrm{z}$ upowszechniania się mechanizmów partycypacji. Może się zdarzyć, że władza lokalna w celu zdobycia popularności da mieszkańcom prawo współdecydowania w sprawach, 
które i tak zostałyby rozstrzygnięte po ich myśli. Może więc dojść do instrumentalnego zawłaszczenia tych narzędzi przez organy władzy, przy jednoczesnej aprobacie aktywnych mieszkańców. Jest to aspekt, który nie może zostać pominięty w badaniach nad demokracją lokalną oraz podczas postulowania jej rozwoju. Rozwinie się ona bowiem jedynie wówczas, gdy nie zostanie narzucona odgórnie, ale będzie wynikiem podmiotowego sprawstwa obywateli.

Niniejsze opracowanie zwraca też uwagę na problem deficytu demokracji w gminach Polski, w tym deficytu demokracji bezpośredniej. Jest on połączony z brakiem poczucia wspomnianego uwspólnotowienia oraz z występowaniem zjawisk patologicznych, takich na przykład jak amoralny familizm, charakterystyczny już nie tylko dla małych społeczności, ale coraz częściej także dla dużych ośrodków miejskich. Zauważyć należy również zanik funkcji kontrolnej w gminach, czego efektem bezpośrednim jest spadek zaufania do organów władzy i spadek poczucia wpływu na władzę. Zaledwie 19\% Polaków uważa, że ma wpływ na sprawy kraju, natomiast poczucie obywatelskiego sprawstwa na poziomie lokalnym wykazuje zaledwie $42 \%$. Budowa demokracji zawsze powinna się odbywać oddolnie, jako wyraz ekspresji podmiotowości. Na podstawie badań nad obywatelską inicjatywą uchwałodawczą można wykazać, czy proces ten przebiega prawidłowo, czy też jest narzucany odgórnie - przez struktury władzy zarówno formalne, jak i nieformalne. Poziom poczucia wspólnoty wyrażony może być w wielu aspektach, między innymi w debacie publicznej o zakresie gminnym, w poczuciu odpowiedzialności za losy gminy, poczuciu współudziału i współdecydowania, ale również poprzez zaufanie obywateli w wymiarze zarówno horyzontalnym, jak i wertykalnym, wynikające z podejścia członków organów władzy do współpracy z obywatelami. Proces wsparcia partycypacji jest obecnie niewydolny. Należy zauważyć, że deficyt podmiotowej aktywności obywateli w Polsce dostrzegany jest również przez Radę Ministrów. W swoim strategicznym programie na lata 2009-2015 zakładała między innymi:

- osiągnięcie optymalnego poziomu uczestnictwa obywateli w życiu publicznym - jako warunek konieczny stworzenia trwałych podstaw dla podmiotowej aktywności obywateli i ich wspólnot w kształtowaniu rozwoju społecznego, wzrostu gospodarczego i kultury politycznej,

${ }^{7}$ Centrum Badania Opinii Społecznej, Poczucie wpływu na sprawy publiczne, Warszawa, wrzesień 2013, s. 3, http://www.cbos.pl/SPISKOM.POL/2013/K_121_13.PDF (dostęp: 29 V 2016). 
- ilościowy i jakościowy rozwój instytucji społeczeństwa obywatelskiego - jako wyraz obiektywnej konieczności wzmocnienia organizacji pozarządowych, integracji społecznej i podmiotów ekonomii społecznej oraz form i sposobów ich funkcjonowania,

- stworzenie mechanizmów funkcjonowania dobrego państwa jako zwieńczający konstrukcję społeczeństwa obywatelskiego rezultat działania zasad pomocniczości, partycypacji, partnerstwa oraz dialogu obywatelskiego $\mathrm{w}$ relacji: sprawna administracja publiczna - obywatele ${ }^{8}$.

\section{Definicja obywatelskiej inicjatywy uchwałodawczej}

Pojęcie obywatelskiej inicjatywy uchwałodawczej należy rozumieć w sposób dwojaki. Przede wszystkim w kategorii podmiotowej jest to konkretna forma podmiotowej aktywności obywateli wynikająca z prawa konstytucyjnego, polegająca na wniesieniu przez obywateli projektu aktu prawa do organów władzy samorządowej. Stosując formalno-prawną kategorię pojęciowa, jest to wynikające z prawa uprawnienie do wniesienia przez mieszkańców danej jednostki samorządu terytorialnego projektu aktu prawa do organów władzy samorządowej. W tym ujęciu jest to więc przepis prawny umożliwiający wystąpienie z obywatelską inicjatywą uchwałodawczą. Podstawowym celem takiej inicjatywy jest zmiana prawa lokalnego lub zmiana praktycznej rzeczywistości, a także sprawczy wpływ obywateli na organy władzy.

Obywatelska inicjatywa uchwałodawcza jako taka nie ma podstaw prawnych osadzonych w źródłach prawa powszechnie obowiązującego. Jedyną jej podstawą prawną mogą być konkretne przepisy w statutach poszczególnych gmin. Wynika stąd, że gminy, które wprowadziły takie prawo w swoich lokalnych ustrojach, korzystają z zasad przewidzianych wyłącznie swoim prawem lokalnym. Zasady występowania z obywatelską inicjatywą uchwałodawczą w poszczególnych gminach mogą być i często są różne. Konkretne gminy określają tryb, sposób, liczbę osób mogących wystąpić z inicjatywą oraz wzory formularzy do wypełnienia przez inicjatorów. Występuje tutaj istotny problem braku odgórnych regulacji w aktach prawa powszechnie obowiązującego. Wprowadzenie przepisu regulującego kwestię obywatelskiej inicjatywy uchwałodawczej

${ }^{8}$ Strategia wspierania rozwoju społeczeństwa obywatelskiego $\mathrm{w}$ Polsce na lata 2009-2015, załącznik do uchwały nr 240/2008 Rady Ministrów z dnia 4 XI 2008 r., sygn. RM 111-241-08. 
w Ustawie z dnia 8 marca 1990 r. o samorządzie gminnym ${ }^{9}$ rozwiązałoby nie tylko dylematy praktyczne, ale i prawne. Kolejnym istotnym aspektem omawianego zagadnienia jest liczba osób mogących wystąpić $\mathrm{z}$ ową inicjatywą $\mathrm{w}$ danej gminie, a także reprezentatywność takiej grupy, która różni się w poszczególnych gminach i wynosi od nieco ponad procenta do dziesiętnych części procenta mieszkańców posiadających czynne prawo wyborcze. Ustawowe uregulowanie tej kwestii z jednej strony usystematyzowałoby reprezentacyjność (określając ją na poziomie procentowym w stosunku do liczby mieszkańców posiadających czynne prawo wyborcze), z drugiej zaś strony stanowiłoby prawnie narzucony przepis, który nie uwzględniałby dodatkowych czynników o charakterze lokalnym. Kluczowe będzie tu więc ustalenie, czy istnieje potrzeba uregulowania tej kwestii przepisami rangi ustawy. Traktowanie statutów gmin jako jedynych podstaw prawnych obywatelskiej inicjatywy uchwałodawczej spotyka się z krytyką. Głównym zarzutem jest brak podstawy prawnej do umieszczania takich przepisów w statutach, do czego przychyla się również Wojewódzki Sąd Administracyjny (WSA) we Wrocławiu w wyroku z 3 kwietnia 2006 r. ${ }^{10}$ Ani ustawa o samorządzie gminnym, ani też Konstytucja Rzeczypospolitej Polskiej ${ }^{11}$ takiego prawa nie przewidują. Ustawa o samorządzie gminnym wskazuje natomiast, że "o ustroju gminy stanowi jej statut", a kwestię inicjatywy uchwałodawczej można traktować jako stricte ustrojową. O ile prawa do obywatelskiej inicjatywy uchwałodawczej nie da się wywieść z art. 4 ust. 1 Konstytucji RP, który brzmi: „Władza zwierzchnia w Rzeczypospolitej Polskiej należy do Narodu", o tyle też nie można wnioskować o braku takiej możliwości na podstawie art. 169 ust. 1 tego aktu, który stanowi: „Jednostki samorządu terytorialnego wykonują swoje zadania za pośrednictwem organów stanowiących i wykonawczych". Tak więc w powszechnie obowiązujących źródłach prawa nie odnajdzie się przepisów wprost zabraniających wprowadzania w statutach gmin takiego prawa, ale również ciężko wywnioskować istnienie jakichkolwiek podstaw prawnych ${ }^{12}$. Jedyną podstawą prawną może być Kodeks

${ }^{9}$ Dz.U. Nr 16, poz. 95.

${ }^{10}$ Wyrok WSA we Wrocławiu z 3 IV 2006 r., sygn. III SA/Wr 584/05, http://orzeczenia. nsa.gov.pl/doc/5D8E8D407B (dostęp: 29 V 2016).

${ }^{11}$ Konstytucja Rzeczypospolitej Polskiej z dnia 2 IV 1997 r. (Dz.U. Nr 78, poz. 483 ze zm.), dalej „Konstytucja RP”.

${ }^{12}$ G. Makowski, Obywatelska inicjatywa uchwałodawcza, prawo i praktyka, w: Dyktat czy uczestnictwo? Diagnoza partycypacji publicznej w Polsce, pod red. A. Olech, Warszawa 2012, s. 289-291. 
postępowania administracyjnego, który umożliwia złożenie wniosku do właściwych organów, w tym organów publicznych. Wykorzystując ten tryb, można na podstawie przepisów prawa powszechnie obowiązującego wystąpić z obywatelską inicjatywą uchwałodawczą.

Obywatelska inicjatywa uchwałodawcza może przyjąć dwie podstawowe formy:

- statutową - opartą na przepisach prawa lokalnego danej gminy będzie to wniesienie projektu aktu prawa lokalnego przez grupę mieszkańców na podstawie przepisów lokalnych;

- wnioskową - pod postacią wniosku o podjęcie uchwały, złożonego do organu stanowiącego na podstawie przepisów Kodeksu postępowania administracyjnego ${ }^{13}$.

Są to główne, ale nie jedyne możliwości inicjowania przez obywateli procesu uchwałodawczego. W sposób pośredni obywatele mogą zgłaszać się do organów władzy, występować z postulatami na sesjach lub bezpośrednio kontaktować się z radnymi. Ponadto istnieje możliwość wnioskowania do burmistrza o wystąpienie z inicjatywą uchwałodawczą. Formy pośrednie, co prawda, wskazują na podmiotowość obywateli, ich dążenie do uzyskania wpływu na sferę polityczna, lecz oznaczają również brak świadomości odnośnie do mechanizmów o charakterze bezpośrednim.

Proces legislacyjny musi zostać poprzedzony pracami nad obywatelskim projektem. Prace te są różne w poszczególnych gminach. O ile projekty obywatelskie procedowane są $\mathrm{w}$ taki sam sposób jak projekty składane przez radnych czy burmistrzów, o tyle często pojawiają się dodatkowe ograniczenia. Takim ograniczeniem mogą być terminy, które grupa inicjująca projekt musi spełnić, aby go przedłożyć. Pozostając przy terminach, niekiedy organy stanowiące mają długi czas na rozpatrzenie projektu obywatelskiego - 3 miesiące, albo nawet pół roku. Poza tym często wymaga się dopełnienia od grupy inicjującej kłopotliwej formalności pod postacią podania podstaw prawnych projektu uchwały. Niektóre miasta w Polsce żądają ponadto opinii prawnej ze strony prezydenta miasta, co może dodatkowo zablokować projekt. Duża liczba regulacji formalnoprawnych dotyczących obywatelskiej inicjatywy uchwałodawczej jest charakterystyczna dla dużych miast. W mniejszych gminach zazwyczaj brak takich rozwiązań ${ }^{14}$.

${ }^{13}$ Ustawa z dnia 14 VI 1960 r. Kodeks postępowania administracyjnego (tekst jedn. Dz.U. 2016, poz. 23).

${ }^{14}$ G. Makowski, op. cit., s. 295-296. 
Obywatelska inicjatywa uchwałodawcza jest więc zarówno elementem diagnozy, jak i propozycją leczenia problemów deficytu demokracji lokalnej w gminach. Punktem odniesienia może być hierarchicznie wyższy poziom tworzenia prawa, którym jest niewątpliwie Unia Europejska (UE). W Unii Europejskiej podstawową dysfunkcją był właśnie omawiany deficyt demokracji. Propozycją lekarstwa na ten problem była europejska inicjatywa obywatelska. Jej wprowadzenie nastąiło w konsekwencji starań struktur unijnych zmierzających do przezwyciężenia deficytu demokracji ${ }^{15}$. Można postawić tutaj tezę, że proponowane przez UE rozwiązanie jest skuteczne również na poziomie gminy. Wzorem Unii Europejskiej na poziomie lokalnym w Polsce należałoby wówczas zaproponować pogłębianie procesów demokratyzacji. Jednym z jej aspektów powinno być zwiększenie mechanizmów demokracji bezpośredniej, partycypacji, a także obywatelskiej inicjatywy uchwałodawczej. Rozwiązaniem mogłoby być, po pierwsze, ustanowienie przez ustawodawcę podstaw prawnych dla inicjatyw obywatelskich w jednym spośród powszechnie obowiązujących źródeł prawa, oraz po drugie, stworzenie odpowiednich warunków organizacyjnych dla rozwoju partycypacji obywatelskiej, co byłoby zadaniem zarówno władz, jak i społeczności lokalnych.

\section{Podmiot występujący z obywatelską inicjatywą uchwałodawczą}

Podstawą badań oraz rozważań nad omawianym zagadnieniem jest określenie stanowiska normatywnego wobec podmiotu inicjującego obywatelską inicjatywę uchwałodawczą. Podstawy normatywne znajdują się w Konstytucji RP. Artykuł 30 tego aktu głosi: „Przyrodzona i niezbywalna godność człowieka stanowi źródło wolności i praw człowieka i obywatela. Jest ona nienaruszalna, a jej poszanowanie i ochrona jest obowiązkiem władz publicznych". Ch. Taylor twierdzi, że wewnętrzna natura człowieka jest źródłem podmiotowości jednostki ${ }^{16}$. Wynika z tego, że moc sprawcza w sposób naturalny jest istotą każdej jednostki ludzkiej. Sprawstwo zostaje przez jednostkę uzewnętrznione na drodze od

${ }^{15}$ A. Capik, A. Gniewek, Wprowadzenie do prawa europejskiej inicjatywy obywatelskiej, http://www.euroinfo.krakow.pl/upload/Europejska\%20inicjatywa\%20obywatelska\%20\%20B.\%20Capik\%20A.\%20Gniewek.pdf, s. 11-13 (dostęp: 29 V 2016).

${ }^{16}$ Ch. Taylor, Źródła podmiotowości, Warszawa 2012, s. 345-370. 
jednostki do ogółu: od „ja” do „my”. W sposób pośredni wynika z tego, że obywatelską inicjatywę uchwałodawczą inicjuje podmiot indywidualny jednostka urzeczywistniająca przyrodzoną moc sprawczą na poziomie grupy. Z tak pojmowanej idei człowieka jako istoty zdolnej do samodzielnego decydowania wywodzić należy koncepcję jego uprawnień podmiotowych. Wynika z tego prawo do własnych poglądów oraz prawo do wyrażania swoich racji. Uzmysłowienie sobie przez jednostkę jej potencjału wewnętrznego doprowadziło do uaktywnienia władz konstytutywnych - poznawania oraz pojmowania, co z kolei jest przyczynkiem do samookreślenia oraz samostanowienia jednostki ${ }^{17}$. Jednostka świadoma swego potencjału, swych możliwości i władz, a szczególnie mocy sprawczej, przelewa ją na ogół, czyli społeczeństwo. Nieco inaczej, choć niejako w uzupełnieniu, kwestię podmiotu widzi J.-C. Kaufmann. Autor ten twierdzi, że może on być wytwarzany na gruncie społeczeństwa i w warunkach społecznych z uwzględnieniem czynników zewnętrznych: prawa, ekonomii, polityki ${ }^{18}$. Pamiętać należy, że prawa i wolności jednostki podlegają w Polsce ochronie prawnej. Państwo na gruncie prawodawstwa oraz w swej bieżącej działalności gwarantować musi funkcjonowanie systemu społecznego opartego zarówno na dobru ogółu, jak i na prawach podmiotowych jednostki oraz jej indywidualnej sferze wolności ${ }^{19}$. Alain Touraine postrzega podmiotowość bardzo podobnie, jako prawo każdej jednostki do bycia uznaną i szanowaną w ramach swoich oczekiwań dotyczących wolności i odpowiedzialności ${ }^{20}$.

Samodzielnie określająca się jednostka nie zawsze ma przekonanie, że jej działania przynoszą pożądany skutek. Świadomość skuteczności działań jednostka osiąga poprzez wywołane przez nią zdarzenia albo zmiany zachodzące w otoczeniu społecznym. Świadomość rzeczywistego wpływu na otaczającą rzeczywistość jest podstawową motywacją, przyczynkiem do poczucia tożsamości samodzielnego sprawcy w życiu społecznym. Aby skutecznie realizować podmiotowość w tym zakresie, potrzebne są również konkretne czynniki zewnętrzne, których brak może uniemożliwić jednostce skuteczność działań. Takimi czynnikami w gminach mogą być np.: poziom zaspokojenia potrzeb podstawowych,

${ }^{17}$ K. Dziubka, Obywatelskość jako virtù podmiotu demokracji, Wrocław 2008, s. 12-30.

${ }_{18}$ J.-C. Kaufmann, Kiedy Ja jest innym. Dlaczego i jak coś się w nas zmienia, Warszawa 2013, s. 27-29.

${ }^{19}$ B. Banaszak, Konstytucyjna regulacja praw i wolności jednostki w okresie transformacji ustrojowej w Polsce, w: 25 lat transformacji ustrojowej w Polsce i w Europie Środkowo-Wschodniej, pod red. E. Gdulewicz, W. Orłowskiego, S. Patyry, Lublin 2015, s. 185-186.

${ }^{20}$ A. Touraine, Po kryzysie, Warszawa 2013, s. 145-147. 
poziom bezrobocia, dostęp do rozrywki, oświaty i kultury, ale również wola polityczna występująca w organach władzy czy proces uwspólnotowienia danej gminy. Granicami dla zewnętrznej podmiotowości obywatela są normy prawne, które określają ogólne warunki, oraz kryteria, których spełnienie jest wymagane w celu konkretnego podmiotowego oddziaływania na rzeczywistość społeczną i polityczną ${ }^{21}$ W wymiarze wertykalnym podmiotowość jednostki rozbija się o kontakt na linii podmiot - przedmiot, czyli obywatel - instytucja władzy. W ten właśnie sposób obywatel może swoje wyobrażenie o funkcjonowaniu gminy urzeczywistniać poprzez różnego rodzaju mechanizmy o charakterze sprawczym - na podstawie i w granicach prawa. Realizacja podmiotowości sprawczej rozbija się zawsze o dwie kwestie: o pasywność oraz o aktywność. Gra aktywności i pasywności jest wyrazem nowoczesnego sprawstwa. Sprawstwo realizuje się w sposób aktywny poprzez mechanizmy, instytucje, urzędy. Natomiast członkostwo i uczestniczenie $w$ tych mechanizmach, instytucjach i urzędach ma już charakter pasywny. Pasywne sprawstwo osiagnięte zostało poprzez poprzednią aktywność i stąd podmiotowe sprawstwo dzisiaj nie odbywa się bez obu tych form ${ }^{22}$. Pragmatycznym przykładem tej relacji mogą być wybory samorządowe, w których samodzielnie zorganizowana grupa społeczna aktywnie uczestniczy poprzez wystawienie list kandydatów oraz sam akt wyborów, a następnie jej przedstawiciele w sposób pasywny stają się członkami organów przedstawicielskich. To samo dotyczy obywatelskiej inicjatywy uchwałodawczej, gdzie aktywne zainicjowanie prowadzi w konsekwencji do pasywnego uczestnictwa w procesie.

W pojęciu podmiotowości należy wyróżnić dwa podstawowe, różne, a zarazem integralnie związane ze sobą komponenty: aspekt świadomości oraz aspekt aktywności. Z tego punktu widzenia za podmiot należy uznać jednostkę samoświadomą oraz zdolną do działania. Świadomość odnosi się przede wszystkim do więzi o charakterze horyzontalnym. W związku ze społecznym charakterem istnienia człowieka świadomość jest w dużej mierze społeczna. Świadomość własnej podmiotowości i wynikającej z niej podmiotowości społeczeństwa w znaczącym stopniu wpływa na więzi interpersonalne wśród obywateli. Na podstawie obserwacji i doświadczeń życia społecznego jednostki kształtują swoje indywidualne orientacje, cele, potrzeby, a także opinie na temat funkcjonowania całej zbiorowości, do której należą. Kształtowanie się

\footnotetext{
${ }^{21}$ K. Dziubka, Obywatelskość jako virtù..., s. 273-308.

${ }^{22}$ A.W. Nowak, Podmiot, system, nowoczesność, Poznań 2011, s. 258-260.
} 
wyżej wspomnianych form jest nieodłącznym elementem tworzenia poczucia więzi wewnątrz grupy, co prowadzi z kolei do poczucia lojalności wobec zasad, norm prawa oraz instytucji. Świadome społeczeństwo samoistnie wewnętrznie reguluje w pewnych aspektach swoje funkcjonowanie, a także normy postępowania, włącznie ze społecznymi sankcjami. Proces tworzenia więzi wynikający z podmiotowości indywidualnej jednostki łączy się nie tylko z formalnymi aspektami, ale przede wszystkim z zachowaniami metaspołecznymi, takimi jak poczucie więzi, świadomość kultury, tradycji i historii swojej gminy, identyfikacja, patriotyzm lokalny, a także tzw. „pamięć historyczna"23. W idealnym modelu społeczeństwo samoświadome, obdarzone wyżej wymienionymi cechami, a także odczuwające potrzeby o charakterze obywatelskim, określone wysokim poziomem wzajemnych więzi interpersonalnych, zaczyna wpływać na struktury władzy oraz na instytucje prawne oraz polityczne.

\section{Mechanizmy prawne partycypacji obywatelskiej na poziomie samorządu gminy}

Partycypacja prawna i polityczna obywateli jest praktyczną formą odzwierciedlenia ich poczucia podmiotowości. Już samo uświadomienie podmiotowości przez obywateli nakłada na nich normy o charakterze zarówno praw, jak i obowiązków w sferze politycznej. Wiedza na temat podmiotowości wpływa na zachowania. Jednostki wyrażają chociażby chęć aktywnego uczestnictwa w życiu politycznym określonym jako aktywny udział w tworzeniu prawa i sytuacji życia publicznego. Obywatele mający świadomość, że porządek prawny stanowi dorobek ich działań i wynika $z$ ich podmiotowości, odpowiedzialnie tego prawa przestrzegają, a także napiętnują tych, którzy prawo łamią. Ich postawa pełni więc obywatelską funkcję wewnętrznej autoregulacji. Społeczeństwo świadome swojej podmiotowości aktywnie współpracuje z władzą. Wie, skąd wzięły się osoby zasiadające w stanowiących organach przedstawicielskich, w urzędach, w organach władzy wykonawczej. Radni, wójtowie, burmistrzowie i prezydenci miast wybrani przez świadome swej podmiotowości społeczeństwo o wiele chętniej z tym społeczeństwem współpracuja, realizują społecznie potrzebne postulaty, są otwarci na

${ }^{23}$ K. Dziubka, Teoria demokratycznej obywatelskości - zarys problemu, w: W. Bokajło, K. Dziubka, Społeczeństwo obywatelskie, Wrocław 2001, s. 96. 
mechanizmy demokracji lokalnej - również te o charakterze bezpośrednim. Dobrze współpracujące z władzą społeczeństwo powinno wyrażać się następującymi cechami podstawowymi:

- wysokim stopniem zaufania do władzy,

- znajomością mechanizmów demokratycznych wynikających z przepisów prawa,

- znajomością przedstawicieli oraz ich zadań i obowiązków względem społeczeństwa.

Ustalenie poziomu występowania tychże cech społeczeństw w poszczególnych gminach może dać odpowiedź na pytanie dotyczące relacji między poczuciem podmiotowości a partycypacją w sferze politycznej. Wspomniana powyżej konstrukcja stanowi wyidealizowany model, który powinien być stosowany jako punkt odniesienia w badaniach nad społecznościami lokalnymi. Występują bowiem jeszcze inne, dodatkowe implikacje. Taką implikacją - stosując odwrócony argument - może być wpływ partycypacji na poczucie podmiotowości. Społeczeństwo o niskim stopniu partycypacji politycznej będzie w tym rozumieniu społeczeństwem o słabym poczuciu podmiotowości.

Relacje między partycypacją polityczną obywateli a poczuciem podmiotowości są wprost wyrażone w sprawstwie o charakterze normatywnym. Partycypacja polityczna to nie tylko wybory, to nie tylko współpraca $z$ organami władzy w trakcie trwania ich kadencji. To nie tylko aktywne współuczestniczenie w życiu politycznym o charakterze miękkim. Obywatele w ramach sprawstwa o charakterze bezpośrednim korzystać mogą z następujących mechanizmów o charakterze prawnego sprawstwa:

- wybory samorządowe,

- ewentualne odwołanie rady,

- obywatelska inicjatywa uchwałodawcza,

- konsultacje społeczne,

- budżet partycypacyjny,

- referendum lokalne,

- fundusz sołecki.

Konsultacje społeczne są procesem, w którym przedstawiciele władz przedstawiają obywatelom swoje plany. Mogą one dotyczyć zarówno sfery pragmatycznej (np. inwestycje), jak i prawnej (np. uchwalenie nowego prawa lub zmiana istniejących przepisów). Konsultacje społeczne są sposobem pozyskiwania informacji i opinii od społeczeństwa. Podstawą prawną do przeprowadzenia konsultacji społecznych w gminach są: 
Ustawa z dnia 8 marca 1990 r. o samorządzie gminnym ${ }^{24}$ oraz Ustawa z dnia 24 kwietnia 2003 r. o działalności pożytku publicznego i o wolontariacie ${ }^{25}$. Gminy mają obowiązek przeprowadzenia konsultacji tylko w sprawach przewidzianych ustawami. Na podstawie ustaw wyróżnić można więc katalog spraw na poziomie samorządu gminy, które konsultacji wymagają. Będą to: tworzenie, łączenie, dzielenie i znoszenie gmin, ustalanie ich granic (art. 4a u.s.g.), nadawanie gminie lub miejscowości statusu miasta i ustalanie jego granic, ustalanie i zmiana nazwy gmin oraz siedziby ich władz na podstawie art. 4 a ust. $1 \mathrm{w}$ zw. $\mathrm{z}$ art. 4 ust. 1 pkt 2 oraz 3 u.s.g., utworzenie oraz określenie struktury organizacyjnej i zakresu działania gminnej jednostki pomocniczej na podstawie art. 5 ust. 2 i art. 35 ust. 1 u.s.g., a ponadto studium uwarunkowań i kierunków zagospodarowania przestrzennego na podstawie art. 11 oraz miejscowy plan zagospodarowania przestrzennego na podstawie art. 17 Ustawy z dnia 27 marca 2003 r. o planowaniu i zagospodarowaniu przestrzennym ${ }^{26}$. Pozostałe formy konsultacji społecznych nie mają już tak otwartej formuły i dotyczą partnerów zbiorowych, jak chociażby konsultowanie z organizacjami pożytku publicznego projektów aktów prawa lokalnego dotyczących celów statutowych tych organizacji oraz konsultowanie z utworzonymi przez jednostki samorządu terytorialnego radami pożytku publicznego projektów aktów prawa dotyczących realizacji zadań publicznych na podstawie art. 5 ust. 2 ustawy z 2003 r. o działalności pożytku publicznego i o wolontariacie. Katalogi podmiotowe powstałe na podstawie ustaw nie mogą być jednak interpretowane jako brak możliwości swobodnego przeprowadzania konsultacji. Gminy mogą je swobodnie przeprowadzać w dowolnej sprawie. Dlatego też należy zbadać, jak akt konsultacji wygląda w poszczególnych gminach: czy są one przeprowadzane w sprawach, w których nie ma ustawowego obowiązku ich przeprowadzenia, a także czy społeczeństwo chętnie i aktywnie korzysta z tego mechanizmu, dając wyraz swego poczucia podmiotowości. Konsultacje nie muszą mieć skutku prawnego. Moga odnosić natomiast skutek faktyczny - organy władzy przychylą się lub nie do opinii konsultowanego społeczeństwa. Konsultacje społeczne można więc uznać za podstawowy element prawa w ustroju demokratycznym oraz fundament dobrze funkcjonującej realizacji idei samorządu. Aby społeczeństwo chętnie uczestniczyło w konsultacjach,

\footnotetext{
${ }^{24}$ Tekst jedn. Dz.U. 2015, poz. 1515, dalej „u.s.g.”.

${ }^{25}$ Dz.U. Nr 96, poz. 873.

${ }^{26}$ Dz.U. Nr 80, poz. 717.
} 
powinien zaistnieć zestaw następujących czynników zewnętrznych. Konsultacje powinny mieć umocowanie prawne jako podstawowa forma komunikowania na linii obywatele - instytucje władzy samorządowej (podmiot - przedmiot). Konsultacje powinny być możliwie rozszerzane i dotyczyć możliwie największej liczby zadań własnych oraz zleconych gminy. Powinno nastąpić umożliwienie obywatelom jako podmiotom w sferze politycznej wnioskowania o przeprowadzenie konsultacji społecznych. Wyróżnić można również potrzebę rozszerzenia edukacji społecznej jako jednego z impulsów partycypacji obywatelskiej. Finalnym wymogiem jest stworzenie raportu podsumowującego przebieg konsultacji ${ }^{27}$. Pamiętać jednak należy, że obecnie obserwowany w Polsce wzrost zainteresowania konsultacjami społecznymi jest społeczną reakcją na deficyt demokracji rozumiany jako odizolowanie się elit władzy od społeczeństwa, spadek zaufania do instytucji politycznych, a także niskie wskaźniki tradycyjnego uczestnictwa ${ }^{28}$.

Budżet partycypacyjny jest prawnym mechanizmem partycypacji ugruntowanym $\mathrm{w}$ aktach prawa miejscowego. Jest to proces decyzyjny polegający na współtworzeniu przez mieszkańców budżetu danej jednostki samorządu terytorialnego w zakresie i granicach przewidzianych prawem. Polega to przeważnie na wyrażonej w głosowaniu decyzji dotyczącej przeznaczenia pewnej puli środków pieniężnych na wybrane przez mieszkańców cele. Cele te zazwyczaj przybierają postać projektów. Przeważnie dotyczy to celów inwestycyjnych. Budżet partycypacyjny, zwany też obywatelskim, ma kilka podstawowych cech. Po pierwsze, do jego realizacji potrzebna jest publiczna debata mieszkańców. Ten mechanizm daje więc szansę rozwoju relacji horyzontalnych podmiot podmiot i przelania ich dorobku na relacje wertykalne podmiot - przedmiot. Po drugie, wspomniana debata odbywa się w ściśle określonych granicach, które stanowi ograniczona ilość środków do rozdysponowania. Po trzecie, budżet partycypacyjny dotyczy całej gminy i nie powinien być mechanizmem realizacji partykularnych interesów poszczególnych osiedli, ulic czy jednostek pomocniczych. Po czwarte, jego wyniki są wiążące. Po piąte, nie jest to zdarzenie incydentalne, ale forma powtarzana corocznie przez lata. Budżet partycypacyjny jest dzisiaj przez

${ }^{27}$ J. Lewinowski, Cele i formy konsultacji, „Biuletyn Forum Debaty Publicznej” nr 33, Cele, granice, metody i koszty lokalnych konsultacji społecznych, maj 2014, s. 15-16.

${ }_{28}$ A. Przybylska, Jaka przyszłość maja w Polsce deliberatywne formy konsultacji społecznych?, w: Partycypacja społeczna. Od teorii do praktyki społecznej, pod red. A. Przybylskiej, A. Gizy, Warszawa 2014. 
gminy traktowany jako narzędzie decentralizacji ${ }^{29}$. Dobrymi przykładami realizacji budżetu obywatelskiego są Kraków, Legnica oraz Wałbrzych.

Referendum lokalne jest podstawowym mechanizmem sprawstwa politycznego wyrażającego poczucie podmiotowości. Mieszkańcy w referendum w sposób prawnie skuteczny podejmują decyzje co do ważnych dla ich gminy spraw. Inicjatorem referendum najczęściej jest grupa inicjatywna. Podkreślić należy, że referendum na każdym poziomie realizacji ma następujące zalety: powoduje zmuszenie reprezentantów do należytego wykonywania obowiązków oraz wywiązania się z obietnic, umożliwia weryfikowanie działań rządzących, wpływa na wzrost znaczenia kwestii ważnych dla mniejszości, edukowanie polityczne i obywatelskie ${ }^{30}$. Nie jest ono jednak pozbawione wad. Za podstawowa uważa się czas przygotowania i realizacji. Nie da się tego instrumentu demokracji bezpośredniej stosować w nagłych przypadkach. Ponadto przedmiotem referendum jest zazwyczaj projekt, który się przyjmuje lub odrzuca, co uniemożliwia całkowite uzewnętrznienie opinii obywateli. Realizacja referendum na szerszą niż epizodyczna skalę może zmienić ustrój w tzw. demokrację plebiscytarną ${ }^{31}$.

Referendum lokalne odbywa się na podstawie Ustawy $\mathrm{z}$ dnia 15 września 2000 r. o referendum lokalnym ${ }^{32}$. Zgodnie z jej art. 6 w Polsce referendum lokalne może być przeprowadzane na poziomie samorządu gminy, powiatu oraz województwa. W art. 2 z kolei zapisany został katalog spraw, których referendum może dotyczyć. Są to kolejno: odwołanie organu stanowiącego danej jednostki, wyrażenie woli co do sposobu rozstrzygania sprawy dotyczącej wspólnoty znajdującej się w zakresie zadań i kompetencji organów danej jednostki, w innych istotnych sprawach dotyczacych społecznych, gospodarczych lub kulturowych więzi łączących tę wspólnotę, odwołanie wójta (burmistrza, prezydenta miasta), samoopodatkowanie się mieszkańców na cele publiczne mieszczące się w zakresie zadań i kompetencji organów gminy. Podmioty uprawnione do inicjatywy referendalnej zostały wymienione w art. 6. Po pierwsze, jest to organ stanowiący danej jednostki samorządu terytorialnego, po drugie, $10 \%$ uprawnionych do głosowania mieszkańców gminy lub powiatu, a także 5\% uprawnionych do głosowania mieszkańców województwa. Z punktu widzenia realizacji idei

\footnotetext{
${ }^{29}$ Instytut Obywatelski, Budżet partycypacyjny. Krótka instrukcja obstugi, Warszawa 2013.

${ }^{30}$ M. Bankowicz, Demokracja. Zasady, procedury, instytucje, Kraków 2006, s. 188-189.

${ }^{31}$ Ibidem, s. 189-190.

32 Dz.U. Nr 88, poz. 985.
} 
podmiotowości obywateli istotną formą jest referendum przeprowadzane na wniosek mieszkańców. Katalog podmiotów uprawnionych do wyjścia z inicjatywą referendalną na wniosek mieszkańców zawarty został w art. 11. Są to: grupa co najmniej piętnastu obywateli, którym przysługuje prawo wybierania do organu stanowiącego danej jednostki samorządu terytorialnego, a w odniesieniu do referendum gminnego także pięciu obywateli, którym przysługuje prawo wybierania do rady gminy; statutowa struktura terenowa partii politycznej działająca w danej jednostce samorządu terytorialnego, przy czym na podstawie ust. 1a prawo inicjatywy referendalnej mieszkańców w sprawie utworzenia, połączenia, podziału i zniesienia gminy oraz ustalenia granic gminy przysługuje jedynie grupie piętnastu obywateli posiadających czynne prawo wyborcze do rady gminy. Poddając przytoczone przepisy dotyczące inicjatywy referendalnej mieszkańców analizie teoretycznoprawnej, rozstrzygnąć należy, w jaki sposób na ich podstawie można realizować podmiotowość rozumianą jako filar społeczeństwa obywatelskiego. O ile statutowe jednostki partii wyrażają we wnioskach referendalnych głównie cele natury politycznej, o tyle w przypadku organizacji pożytku publicznego, a zwłaszcza oddolnej grupy inicjatywnej, tak być nie musi. Dlatego należy zwracać szczególną uwagę na to, jakie cele przyświecały wnioskom referendalnym, jaki podmiot był ich inicjatorem, jakich spraw dotyczyły, a także jaki skutek faktyczny i prawny przyniosły. Skutkiem referendum może być zarówno jego zakończenie pozytywne - zmiana przepisów prawa, odwołanie organu, wydanie opinii pozytywnej lub negatywnej, jak i zakończenie negatywne - brak zmian natury prawnej oraz brak zmian o charakterze faktycznym. Jeśli w referendum głosujący opowiedzą się inaczej, niż to zakładali inicjujący, egzemplifikować to może słaby poziom więzi społecznych, brak jednolitych interesów, a przede wszystkim partykularny lub polityczny charakter referendum. Jeśli głosujący zagłosują zgodnie z założonym celem, oznaczać to może wysoki poziom poczucia wspólnoty interesów. Dlatego też analiza wniosków, a także procesów zdobywania poparcia, samego aktu głosowania i wyniku referendum ukazać może bezpośrednią implikację poczucia podmiotowości do sfery sprawstwa normatywnego.

Ponadto za formę partycypacji politycznej obywateli uznać należy fundusz sołecki funkcjonujący na podstawie Ustawy z dnia 21 lutego 2014 r. o funduszu sołeckim ${ }^{33}$. Jest to mechanizm działający tylko

${ }^{33}$ Dz.U. poz. 301. 
w gminach wiejskich oraz miejsko-wiejskich. Fundusz sołecki to zgodnie $z$ art. 2 przywołanej ustawy środki finansowe pochodzace $z$ budżetu gminy przeznaczone $w$ drodze uchwały rady (w ramach jej zadań własnych i zgodnie ze strategią rozwoju gminy) na przedsięwzięcia służące w sołectwie poprawie warunków życia mieszkańców. Mogą być one również przeznaczone na pokrycie wydatków na działania zmierzające do usunięcia skutków klęski żywiołowej. O sposobie wydatkowania tych środków decydują mieszkańcy na zebraniu wiejskim. Decyzja ta jest wiążąca dla władz gminy - pod warunkiem spełniania wymagań formalnych przez złożony do burmistrza lub wójta wniosek ${ }^{34}$. Zauważyć należy politykę państwa zmierzającą do rozwoju obszarów wiejskich, która w ustawie o funduszu sołeckim została wyrażona. Otóż na podstawie $z$ art. 3 gmina otrzymuje $z$ budżetu państwa zwrot $w$ formie dotacji celowej w wysokości między $20 \%$ a $40 \%$ wykonanych w ramach funduszu sołeckiego wydatków. Oznaczać to może także politykę ustawodawcy zmierzającą do rozwoju kapitału społecznego obszarów wiejskich.

Należy pamiętać o roli organizacji pożytku publicznego w procesie partycypacji obywatelskiej. Funkcjonują one na podstawie ustawy z kwietnia 2003 r. o działalności pożytku publicznego i o wolontariacie. Ustawa ta $\mathrm{w}$ art. 3 zawiera definicję legalną działalności pożytku publicznego, zgodnie z którą jest to „działalność społecznie użyteczna, prowadzona przez organizacje pozarządowe w sferze zadań publicznych określonych w ustawie". Organizacjami pozarządowymi w rozumieniu przepisów tegoż artykułu są jednostki inne niż jednostki sektora finansów publicznych, przedsiębiorstwa, instytuty badawcze, banki i spółki prawa handlowego będące państwowymi lub samorządowymi osobami prawnymi, a także niedziałające w celu osiągnięcia zysku - osoby prawne lub jednostki organizacyjne bez osobowości prawnej, którym odrębna ustawa przyznaje zdolność prawna, w tym fundacje i stowarzyszenia. Są one podstawowymi negocjatorami interesów obywateli w sferze publicznej. Zakres zadań, które wykonuja, jest na tyle szeroki, że można mówić o ich ogromnej roli w funkcjonowaniu sfery publicznej w Polsce. Obszar działalności omawianych organizacji został sklasyfikowany w art. 4 ust. 1 ustawy. Pamiętać należy, że działalność pożytku publicznego może być zgodnie $\mathrm{z}$ art. 3 ust. 3 prowadzona także przez inne wymienione podmioty. O kondycji lokalnego dialogu obywatelskiego

${ }^{34}$ K. Frąckiewicz, Fundusz sołecki, w: Partycypacja obywatelska - decyzje bliższe ludziom, pod red. A. Maszkowskiej, K. Sztop-Rutkowskiej, Białystok 2013, s. 126-130. 
dużo mówi kształt bezpośrednich relacji instytucjonalnych między organizacjami pozarządowymi i administracją. Zgodnie z art. 5a "[o]rgan stanowiący jednostki samorządu terytorialnego uchwala, po konsultacjach z organizacjami pozarządowymi oraz podmiotami wymienionymi $\mathrm{w}$ art. 3 ust. 3 ustawy, może uchwalić, w sposób określony w ust. 1, wieloletni program współpracy z organizacjami pozarządowymi oraz podmiotami wymienionymi $\mathrm{w}$ art. 3 ust. 3 ". Zatem współpraca na linii organizacje pożytku publicznego - władze lokalne jest regulowana w aktach prawa miejscowego. Należy więc zadać pytanie, na ile akty te przewidują kierunek obywatelski i zakładają lokalne oryginalne rozwiązania, a na ile są tylko aktami, które zgodnie z ustawą jako aktem prawa wyższego rzędu rada gminy musi podjąć. Czy zatem współpraca jest prowadzona na zasadzie dialogu czy też regulacji normatywnych i powiązań finansowych? Jakość dialogu obywatelskiego ma bowiem wpływ na poziom partycypacji obywatelskiej w danej gminie. Model współpracy międzysektorowej w Polsce jest dzisiaj jednostronny - opiera się przede wszystkim na współpracy finansowej. W praktyce oznacza to, że organizacje pozarządowe pełnią w większości przypadków funkcję wykonawcy zadań publicznych zlecanych przez administrację. Może to powodować uzależnienie organizacji od sektora publicznego, a także zanik w sektorze pozarządowym funkcji reprezentanta społeczeństwa obywatelskiego. Ukazuje to słabość lokalnego dialogu obywatelskiego, który jest najważniejszym filarem społeczeństwa obywatelskiego ${ }^{35}$.

Partycypacja polityczna jednoczy obywateli. Spoiwem jest tworzona przez nich rzeczywistość, wolna od przymusu i przyjmująca formę dialogu. Jej celem jest zatem tworzenie rozwiązań sprzyjających intensyfikacji więzi między obywatelami. Właściwie zorganizowana wspólnota może realizować swoją wolność nie tylko w komunikacji, ale przede wszystkim w sprawczym działaniu w sferze prawnej. Wówczas władza staje się uzależniona od zgody dobrze zorganizowanych obywateli, a więc tych, nad którymi jest sprawowana. Aktywne uczestnictwo obywateli w sferze publicznej kształtuje więzi, ich rolę oraz status. Włączenie się do życia publicznego jest przyczynkiem do wolności i równości podmiotów. Podstawą podmiotowości nie jest więc praca czy wytwarzanie, charakterystyczne dla doktryn lewicowych, ale polityczna partycypacja i komunikacja we wspólnej sferze publicznej ${ }^{36}$.

${ }^{35}$ P. Sobiesiak-Penszko, Organizacje pozarzadowe a partycypacja publiczna, w: Dyktat czy uczestnictwo..., s. 137-148.

${ }^{36}$ K. Dziubka, Obywatelskość jako virtù..., s. 273-308. 


\section{Obywatelska inicjatywa uchwałodawcza jako element partycypacji w sferze publicznej. Umiejscowienie, przyczyny i skutki}

Aby zrozumieć, w jaki sposób obywatelska inicjatywa uchwałodawcza staje się urzeczywistnieniem podmiotowej mocy sprawczej jednostki, trzeba sięgnąć zarówno do jej podstaw, jak i skutków. Przyczyny zaistnienia obywatelskiej inicjatywy uchwałodawczej mogą być i podmiotowe, i przedmiotowe. Od strony podmiotowej przyczyną jest przede wszystkim realizacja przyrodzonej mocy sprawczej jednostki poprzez samookreślenie i udział w procesie partycypacji obywatelskiej. Jeśli $\mathrm{w}$ danej gminie proces partycypacji przebiega prawidłowo i pozwala dobrze realizować podmiotowość obywateli, to można przyjąć założenie, że obywatelska inicjatywa uchwałodawcza będzie zachodzić regularnie. Do przyczyn przedmiotowych zaliczyć należy przede wszystkim zaistnienie jakiegoś problemu lub potrzeby. Po dostrzeżeniu przez obywateli wspólnego problemu musi dojść do zorganizowania i zawiązania się grupy inicjatywnej, która następnie podejmuje oparte na podstawie prawa działania. Działania te obejmują: ustalenie wspólnego i korzystnego rozwiązania, stworzenie stosownego projektu aktu prawa w formie projektu uchwały, często nagłośnienie i upublicznienie problemu, zebranie odpowiedniej liczby podpisów i finalnie złożenie projektu. Na tym etapie aktywna podmiotowość obywateli przechodzi $\mathrm{w}$ sprawstwo pasywne i uczestniczenie $\mathrm{w}$ dalszym procesie, którym jest procedura prawodawcza. Procedura ta doprowadzi do ustanowienia aktu prawa miejscowego bądź też odrzucenia projektu. Każda z możliwości ma doniosły wpływ na dalszy przebieg wypadków. Przyjęcie aktu prawa oznacza:

1. na gruncie normatywnym: zmianę lub uchwalenie nowych przepisów prawa lokalnego;

2. na gruncie społecznym: wzrost zaufania dla władz gminy, wzrost zadowolenia z życia na danym terenie, większą organizację społeczeństwa, a w dalszej konsekwencji spore szanse na pojawienie się nowych obywatelskich inicjatyw uchwałodawczych.

Brak podjęcia przedłożonego przez obywateli aktu prawa w sposób naturalny nie rodzi żadnych skutków prawnych, natomiast rodzi skutki o charakterze społecznym oraz obywatelskim. Będą to przede wszystkim: spadek zaufania do władzy, spadek zaufania do prawa, wzrost niezadowolenia z życia w danej gminie, spadek aktywności obywatelskiej 
na gruncie partycypacji obywatelskiej, a w dalszej konsekwencji poczucie oderwania się prawa lokalnego od obywatela.

Obywatelska inicjatywa uchwałodawcza do zaistnienia potrzebuje odpowiednich warunków. Podstawowym będzie świadomość obywateli jako podmiotów uprawnionych do skutecznych działań w sferze publicznej. Jeśli nie wystąpi społeczne przekonanie o realnym wpływie na władze, inicjatywa obywatelska nie będzie występować w sposób powtarzalny. Poczucie takiego sprawstwa spowodowane jest w dużym stopniu zaufaniem do prawa. Ponadto społeczeństwo danej gminy powinno postrzegać lokalną przestrzeń publiczną jako obszar kolektywnej współpracy. $W$ przeciwnym razie obywatelska inicjatywa uchwałodawcza wystąpić może tylko w formie jednorazowej i partykularnej - będącej próbą realizacji interesu jednostkowego, nie zaś społecznego. Powinno również występować wśród obywateli poczucie współodpowiedzialności. Obywatel jest odpowiedzialny za państwo, za jednostkę samorządu terytorialnego, a także za tworzone prawo. Podstawą zrozumienia odpowiedzialności jest otwarta komunikacja interpersonalna, odpowiedni poziom dialogu publicznego oraz przede wszystkim wzajemne zaufanie. Należy zauważyć, że obywatelska inicjatywa uchwałodawcza wywodzi się z kapitału społecznego. Ten zaś odnosi się do takich cech organizacji społeczeństwa, jak zaufanie, normy i powiązania, które mogą zwiększyć sprawność społeczeństwa, ułatwiając skoordynowane działania ${ }^{37}$. Zaistnienie w sposób skuteczny obywatelskiej inicjatywy uchwałodawczej prowadzi do wzmocnienia wyżej wymienionych czynników, które uznać można za dobre warunki w sferze publicznej do jej wystąpienia. Obywatelska inicjatywa uchwałodawcza jest więc bardzo ważnym mechanizmem partycypacji społeczeństwa w życiu samorządowym. Stanowi ona zarówno skutek, jak i przyczynę innych mechanizmów.

\section{Stopień budowy wspólnot lokalnych w gminach}

Każda z polskich gmin ma swoją indywidualna, ekskluzywną historię, kulturę i tradycję. Nie w każdej te wartości są pielęgnowane, chociaż niewątpliwie to właśnie one budują poczucie wspólnoty. Pamiętać należy, że trwają one nie tylko z obecnymi mieszkańcami danej gminy.

${ }^{37}$ R. Putnam, Demokracja w działaniu: tradycje obywatelskie we wspótczesnych Włoszech, Kraków 1995, s. 258. 
Specyfiką Polski jest młodość jej granic. Wiele obszarów zostało do Polski przyłączonych w $1945 \mathrm{r}$. Najlepszym przykładem są granice zachodnie, ze szczególnym uwzględnieniem województwa dolnośląskiego. Obecni mieszkańcy tych ziem mają stosunkowo niewielki stopień zasiedzenia, a tradycje kulturalno-historyczne budowane były już przez poprzednich mieszkańców. Ich wyrazem są cmentarze, muzea, zabytki, ośrodki kultury, a także dobra materialne pozostawione przez byłych mieszkańców po zmianie granic na podstawie Układu zgorzeleckiego z 6 lipca 1950 r. Przedstawione wartości są spoiwem dla tworzenia społeczności lokalnych, dla budowy więzi. Zasiedlanie tych terenów w okresie powojennym było odgórną próbą stworzenia wspólnot. Taka próba oczywiście musiała się skończyć niepowodzeniem. Dlatego należy postawić pytanie, czy opierając się na przywołanych powyżej wzorcach, społeczności lokalne tworzą więzi oraz czy dążą do pielęgnacji wartości budujących wspólnotę, a także jakie wartości w Polsce budują wspólnoty lokalne. Czy są to wartości pozostawione przez poprzedników czy też wartości narodowe, czy może jeszcze inne wartości?

Gminy w zachodniej Polsce, w tym również w województwie dolnośląskim, są dość często zasiedlane przez osoby pochodzące z zagranicy. Przy tym nie jest to tylko specyfika gmin miejskich, w przypadku których to sprawa naturalna wynikająca z przyczyn ekonomicznych, zawodowych i naukowych - ale również gmin miejsko-wiejskich oraz wiejskich. Nowi mieszkańcy - nierzadko pochodzący z Niemiec - są członkami wspólnoty, sa pełnoprawnymi uczestnikami procesu partycypacji obywatelskiej w tych gminach. Kolejną kwestią podejmowaną w niniejszym artykule jest próba ukazania i odpowiedzi na pytanie, czy osoby innego pochodzenia są również pełnoprawnymi członkami wspólnot na płaszczyźnie pragmatycznej. Kluczem będzie tu określenie, kim są "inni” - czy to tylko cudzoziemcy czy też przyjezdni z innych miast, czy może po prostu osoby poprzez ubiór, styl bycia czy orientację seksualną wyróżniające się w danym środowisku. Sposób, w jaki tzw. inni są traktowani - dopuszczani do bycia pełnoprawnymi członkami bądź spychani na margines wspólnoty - opowie o tym, jak wspólnota się buduje i samodzielnie określa. Dlatego bardzo istotne jest zbadanie, czy w Polsce zachodzi zjawisko amoralnego familizmu. Jest to zjawisko polegające na poczuwaniu się do obowiązków moralnych i etycznych tylko względem własnej rodziny i osób bezpośrednio powiązanych siatką zależności i interesów. Postawa ta bierze się z dualizmu postaw podziału na świat ludzi i świat instytucji, a następnie innych zachowań 
natury etyczno-moralnej w stosunku do przedstawicieli obu światów. W społeczeństwie polskim początków amoralnego familizmu doszukiwać się można w latach osiemdziesiątych ubiegłego wieku, kiedy to obywatele tworzyli alternatywny świat dla skonfliktowanej z nimi władzy centralnej. Powstały wówczas sieci zależności. Nastąpiło zjawisko wycofywania się aktywnych obywateli do sfery prywatnej, a następnie tworzenia alternatywnej, niezależnej od władz sfery publicznej. Skutkiem tego stały się podziały społeczne, dbanie o prywatne interesy, brak spojrzenia na dobro wspólne społeczeństwa. Amoralny familizm dzisiaj to sieć powiązań o charakterze nieformalnym, których trzonem jest rodzina lub - w szerszym rozumieniu - koalicja rodzin będąca w stanie wzajemnych zależności. Zjawisko to cechuje:

- zawężenie percepcji świata oraz strategii życiowej do rodziny;

- poczucie braku kontroli zewnętrznej;

- materialny interes rodziny jako cel główny działalności;

- brak zdolności do działań dla dobra wspólnego społeczeństwa.

Społeczeństwo, w którym występuje zjawisko amoralnego familizmu, to społeczeństwo zatomizowane, podzielone na małe grupy, społeczeństwo mikrostruktur, sieci nieformalnych powiązań, rywalizujących ze sobą ludzi, którzy są dla siebie obcy, a nawet wrogo nastawieni i mający sprzeczne interesy. Specyfiką takiego społeczeństwa jest indywidualistyczna i egoistyczna orientacja połączona z dualizmem moralnym i etycznym. Jednostki $w$ tak zorganizowanym społeczeństwie uznają pewne zasady moralne za obowiązujące tylko wobec jednostek lub grup najbliższych sobie. Postępowanie przeciwne w stosunku do jednostek obcych nie uchodzi za nieetyczne i amoralne, ale wręcz za potrzebne i godne pochwały ${ }^{38}$. Taka działalność prowadzi do spadku zaufania społecznego. Zaufanie z kolei jest podstawowym elementem życia społecznego. Cechą charakterystyczną społeczeństwa Polski jest niski poziom zaufania w wymiarze wertykalnym oraz horyzontalnym uogólnionym, przy jednoczesnym wysokim poziomie zaufania w wymiarze horyzontalnym prywatnym. Oznacza to, że stosunki między ludźmi, których łączy pokrewieństwo, znajomość, wspólna praca, sąsiedztwo lub więzi parafialne, niezmiennie się na nim opierają ${ }^{39}$.

${ }^{38}$ E. Tarkowska, J. Tarkowski, Amoralny familizm, czyli o dezintegracji społecznej w Polsce lat osiemdziesiątych, w: J. Tarkowski, Socjologia świata polityki, t. 1, Warszawa 1994, s. $263-281$.

${ }^{39}$ M. Mularska-Kucharek, Zaufanie jako fundament życia społecznego na podstawie badań w województwie tódzkim, "Studia Regionalne i Lokalne” 2011, nr 2(44), s. 80. 
Kolejnym aspektem są organizacje lokalne zrzeszające ludność, czyli tzw. trzeci sektor. Aktywność obywateli realizowana w organizacjach non profit może być uznawana za wyznacznik społeczeństwa obywatelskiego, przede wszystkim dlatego, że jakość społeczeństwa obywatelskiego zależy od umiejętności podejmowania wspólnych działań. Pamiętać też należy, że o sile omawianych organizacji, co prawda, w pewnym stopniu decydują zasoby materialne, ale najważniejsza jest w nich aktywność obywateli ${ }^{40}$. Do trzeciego sektora należą nie tylko stowarzyszenia, kluby sportowe czy organizacje pożytku publicznego. Ludność zrzeszają także Kościoły i związki wyznaniowe, koła gospodyń wiejskich, kluby wiejskie i świetlice. Ich wpływ na budowę lokalnych społeczności jest nieoceniony i powinien zostać poddany badaniom. To w tych małych grupach rodzą się najczęściej pomysły i inicjatywy budujące poczucie więzi, podtrzymujące lokalne wartości i prowadzące do budowy tożsamości lokalnej. Duża aktywność tych grup jest wyrazem prawidłowo funkcjonujących społeczności, działających oddolnie, bez odgórnej ingerencji struktur władzy. Podkreślić należy, że w sposób szczególny dzisiaj niedoceniana jest rola Kościoła katolickiego w zakresie budowy tożsamości lokalnej. Parafie można i należy traktować jako bardzo bogate źródło wiedzy dotyczącej polskiego społeczeństwa ze względu na fakt, że liczba wiernych w Polsce to ponad $90 \%{ }^{41}$. Z drugiej strony Kościół katolicki, pracując w terenie, bardzo często poprzez akcje o charakterze patriotycznym i lokalnym dba o ciągłość pamięci historycznej, a także aktywizuje obywateli. W gminach wiejskich ogromne znaczenie ma również działalność świetlic, bezpośrednio z nimi sprzężona działalność kół gospodyń wiejskich oraz jednostek ochotniczych straży pożarnej. Aktywizacja ludności wiejskiej na ziemiach Polski odbywa się właśnie w ramach wyżej wspomnianych struktur społecznych. Budowanie wspólnoty, świadomość własnych potrzeb grupowych i środowiskowych realizowana jest poprzez aktywność urzeczywistnioną w ramach tych form organizacyjnych.

W dobie rewolucji informacyjnej spora część życia społecznego przenosi się do Internetu. Tak stało się początkowo z życiem publicznym o charakterze międzynarodowym, następnie z ogólnokrajową sferą publiczną, a obecnie owa tendencja przenosi się również na poziom

${ }^{40} \mathrm{G}$. Kopiec, Aktywność obywatelska w organizacjach non profit jako wyznacznik społeczeństwa obywatelskiego, w: Rozdroża praktyki i idei społeczeństwa obywatelskiego, pod red. W. Misztala, A. Kościańskiego, Warszawa 2011, s. 181, 189.

${ }^{41}$ Dane za: GUS, Wyznania religijne, stowarzyszenia narodowościowe i etniczne w Polsce w latach 2006-2008, Warszawa 2010, s. 36. 
społeczności lokalnych. Oznacza to, że skutki rewolucji informacyjnej są wielopłaszczyznowe i znajdują odzwierciedlenie w różnych aspektach życia obywateli i tworzonych przez nich społeczności. Skutki te widoczne są nie tylko na płaszczyźnie ekonomicznej, psychologicznej czy środowiskowej, ale również społecznej i politycznej. Rewolucja informacyjna wywiera więc realny wpływ na transformację społeczną. Nowe technologie przekazywania informacji stanowią katalizator przemian społecznych ${ }^{42}$. Strony internetowe posiadają dzisiaj zarówno urzędy, jak i instytucje publiczne w poszczególnych gminach. Poza tym strony dotyczące lokalnych społeczności zakładają często aktywni obywatele bez uprzednich kontaktów i powiązań z lokalną administracją. Ponadto samoistny rozwój portali społecznościowych doprowadził do powstania profili oraz grup zrzeszających mieszkańców danych gmin. Tego rodzaju portale i profile są dzisiaj obliczem i wyrazem aktywności obywatelskiej poszczególnych gmin w sieci. Ich analiza pozwala na ustalenie, jak aktywność obywatelska w wybranych jednostkach rozwija się w ogóle. Jest to istotne źródło poznawcze i badawcze.

Kształtowanie się wspólnoty lokalnej jest procesem o charakterze sprzężenia zwrotnego. Z jednej strony samo powstawanie tożsamości wspólnoty ma charakter ciągły i jest generowane dzięki cechom indywidualnym jej członków. Z drugiej zaś - tożsamość indywidualna obywateli tworzy się dzięki ich silnemu poczuciu przynależności do wspólnoty ${ }^{43}$. Analiza wymienionych wyżej zjawisk na poziomie wybranych gmin pozwoliłaby wykazać, jak wygląda proces budowy wspólnot, a także jak przekłada się on na aktualny stan demokracji lokalnej w różnych gminach. Badanie tych aspektów jest istotne, gdyż jego wynik pozwoli na ukazanie, czy i w jakim stopniu w badanych polskich gminach występują warunki pozwalające na zaistnienie obywatelskiej inicjatywy uchwałodawczej jako konkretnej formy podmiotowej aktywności obywateli. Obywatelskość jest przede wszystkim przywiązaniem do całości społeczeństwa. Objawia się decyzjami oraz działaniami, które zmierzają do ochrony oraz pomnażania dobra społeczeństwa jako całości. Tak rozumiana zbiorowa samoświadomość ogranicza i kształtuje działania jednostek ${ }^{44}$.

${ }^{42}$ M. Leszczyńska, Współczesny model rozwoju społecznego z perspektywy rewolucji informacyjnej, w: Nierówności społeczne a wzrost gospodarczy. Społeczeństwo informacyjne regionalne aspekty rozwoju, pod red. M. Woźniaka, Rzeszów 2011, s. 125.

${ }^{43}$ K. Dziubka, Obywatelskość jako virtù..., s. 259-273.

${ }^{44}$ E. Shils, Co to jest społeczeństwo obywatelskie?, w: Europa i społeczeństwo obywatelskie. Rozmowy w Castel Gandolfo, pod red. K. Michalskiego, Kraków 1994, s. 9-53. 


\section{Jawne i ukryte mechanizmy władzy gminnej}

Zgodnie z art. 11 u.s.g. władzę w gminie sprawują jej mieszkańcy. Rozstrzygnięcia podejmowane są przez mieszkańców w jednej z dwóch form: po pierwsze, poprzez wybory, po drugie, w drodze referendum. Widać tutaj przeniesienie zasad z art. 4 Konstytucji RP, gdzie władza zwierzchnia zostaje powierzona narodowi w sposób pośredni $\mathrm{w}$ wyborach oraz bezpośredni w referendum. Na obu płaszczyznach sprawowania władzy panują porównywalne demokratyczne zasady. Jednak należy pamiętać, że wskutek wyborów powołane zostają organy, które de facto ową władzę sprawują. Będą to, zgodnie $z$ art. 11a ust. 1 u.s.g., wójt (burmistrz, prezydent miasta) oraz rada gminy. Władzę na poziomie samorządu terytorialnego, a więc również na poziomie samorządu gminy, podzielić należy na władzę uchwałodawczą oraz wykonawczą. Organem sprawującym władzę wykonawcza, zgodnie z art. 26 u.s.g., jest wójt (burmistrz, prezydent miasta). Rada gminy, zgodnie z art. 12 u.s.g., jest natomiast organem sprawującym władzę uchwałodawczą oraz kontrolną. Kadencja radnych została wyznaczona w art. 12 ustawy i trwa 4 lata. Kadencja wójta trwa dokładnie tyle samo, a zawarte jest to w art. 26 ust. 1 ustawy. Zarówno radni, jak i wójtowie (burmistrzowie, prezydenci miast) wybierani są $w$ wyborach samorządowych na podstawie obowiązującej Ustawy z dnia 5 stycznia 2011 r. Kodeks wyborczy ${ }^{45}$. Na gruncie jej przepisów można wyróżnić następujące zasady dotyczące polskich wyborów samorządowych: zasadę powszechności zabezpieczoną w art. 10; zasadę równości, ze szczególnym uwzględnieniem równości materialnej zabezpieczonej w art. 373 § 2; zasadę bezpośredniości wprost zapisaną $\mathrm{w}$ art. 369; oraz zabezpieczoną przez art. $52 \S 5$ zasadę tajności głosowania. Zasady te są przeniesieniem zasad wyborczych wynikających z Konstytucji RP ${ }^{46}$. Niemiecki badacz systemów wyborczych Dieter Nohlen uważa, że uznanie wspomnianych zasad daje podstawę funkcjonowania demokracji zachodnich krajów uprzemysłowionych. Wskazuje on, że powszechność, równość, bezpośredniość i tajność wyborów to cechy demokracji pluralistycznych i liberalnych ${ }^{47}$.

Skoro ordynacja wyborcza do organów jednostek samorządu terytorialnego jest prawidłowa, nowoczesna i urzeczywistniająca cechy współczesnych liberalnych demokracji, to należy się zastanowić, co jest

\footnotetext{
${ }^{45}$ Dz.U. Nr 21, poz. 112.

${ }^{46}$ M. Chmaj, System wyborczy w Rzeczypospolitej Polskiej, Warszawa 2011, s. 154-157.

${ }^{47}$ D. Nohlen, Prawo wyborcze i system partyjny, Warszawa 2004, s. 35-51.
} 
przyczyną omawianych dysfunkcji. Pozostając przy kwestii wyborów, zauważyć można następujący kłopot. Otóż zgodnie z art. 4 Kodeksu wyborczego prawo zgłaszania kandydatów w wyborach przysługuje wyłącznie komitetom wyborczym. Z kolei w art. 399 tego aktu ustawodawca wprost wymienia katalog komitetów wyborczych, którym przysługuje prawo zgłaszania kandydatów na radnych. Są to komitety wyborcze partii politycznych, koalicyjne komitety wyborcze, komitety wyborcze organizacji oraz komitety wyborcze wyborców. Pierwsze dwa rodzaje komitetów są urzeczywistnieniem walki politycznej o władzę. Kolejne dwa natomiast w dużym uogólnieniu stanowić mogą urzeczywistnienie podmiotowości lokalnych jednostek. Wymienić można gminy, w których wybory wygrywają komitety partii politycznych. Są jednak też gminy, gdzie wygrywają komitety wyborcze wyborców. Dobrymi przykładami na Dolnym Śląsku są: Komitet Wyborczy Wyborców Rafała Dutkiewicza we Wrocławiu, utworzony w 2010 r., czy Komitet Wyborczy Wyborców Tadeusza Krzakowskiego w Legnicy. Inny reprezentatywny przykład to niewielka dolnośląska gmina Lewin Kłodzki, w której w 2010 r. tylko jeden kandydat na radnego reprezentował komitet partii politycznej - Sojusz Lewicy Demokratycznej, pozostali natomiast reprezentowali komitety wyborcze wyborców ${ }^{48}$. Można więc zakładać, że w gminach, w których wygrywają komitety wyborcze wyborców, mechanizmy władzy sprzyjają urzeczywistnieniu idei podmiotowości obywateli poprzez skuteczny oraz widoczny efekt działań komitetów obywatelskich w postaci wygranych wyborów.

Kluczem do przejścia na dalszy etap rozważań byłoby zatem zbadanie, kiedy i w jakich okolicznościach lokalny społeczny komitet wyborczy wyborców przekształca się w byt o charakterze czysto politycznym, a kiedy pozostaje wciąż praktycznym urzeczywistnieniem realnych potrzeb społecznych. Często nieświadomi swej podmiotowości obywatele wraz $\mathrm{z}$ wrzuceniem karty do urny dają swoim przedstawicielom carte blanche. Tworzy się tym samym podział na "my” - postulujący i wymagający zaspokojenia naszych potrzeb oraz "oni" - od których tego wymagamy i z których jesteśmy niezadowoleni. Taki model jest dysfunkcyjny. Prowadzi do osłabienia mechanizmów partycypacyjnych w postaci chociażby nieefektywnych: konsultacji społecznych (lub ich braku), komunikacji na linii obywatele - władza, a także dialogu publicznego. $W$ takim modelu zanika w obywatelach poczucie współodpowiedzialności za

${ }^{48}$ Wybory samorządowe 2010, http://wybory2010.pkw.gov.pl/geo/pl/020000/ 020000.html (dostęp: 29 V 2016). 
losy gminy, co prowadzi do zanikania współdecydowania. Za wyraz współdecydowania uznają oni jedynie wybory, których frekwencja na przestrzeni ostatnich lat jest niska, a w pierwszej turze wyborów samorządowych w 2014 r. wyniosła $47,4 \%{ }^{49}$.

Nowy kodeks wyborczy wprowadził zasadniczą zmianę w wybieraniu radnych $\mathrm{w}$ gminach niebędących miastami na prawach powiatu. Wybiera się ich zgodnie z art. $418 \S 1 \mathrm{w}$ jednomandatowych okręgach wyborczych. Wpłynęło to niewątpliwie na reprezentatywność władz lokalnych. Jest to istotne dlatego, że rady gmin sa, jak już wspomniano, organami nie tylko stanowiącymi, ale również kontrolnymi gmin. Przypisana została więc im funkcja kontrolna. Urzeczywistnieniem jej wypełniania jest działalność komisji rewizyjnych w radach poszczególnych gmin. Komisje rewizyjne są komisjami rady wyspecjalizowanymi w celu wykonywania funkcji kontrolnej. Funkcję sprawują jednak tylko w zakresie kompetencji rad gmin określonych w art. 18 ustawy o samorządzie gminnym. Ponadto zgodnie z rozstrzygnięciem nadzorczym wojewody wrocławskiego komisje rady nie mogą korzystać z praw i obowiązków ustawowo przypisanych innym organom ${ }^{50}$. W dzisiejszych samorządach w Polsce występuje zjawisko zanikania tej funkcji. Ich aktywność, rozumiana między innymi jako ilość przeprowadzanych przez nie kontroli, jest wyrazem jej realizacji. Komisje rewizyjne ograniczają się głównie do opiniowania wykonania budżetu, wniosku absolutoryjnego oraz rozpatrywania skarg. Inicjowanie dodatkowych kontroli jest zjawiskiem rzadkim, które w wielu gminach wręcz nie występuje. Zanik tej funkcji to de facto carte blanche dla władzy wykonawczej. Deficyt funkcji kontrolnej implikuje spadek zaufania dla władzy, co w konsekwencji prowadzić może do takich zjawisk jak referendum w sprawie odwołania władz lokalnych. Referenda odwoławcze w gminach, a także plany organizacji tego rodzaju głosowań były w kadencji 2010-2014 bardzo częstym zjawiskiem w Polsce, co potwierdzać może tezę o spadku zaufania obywateli do organów władzy. Referendum odwoławcze jest bowiem społecznym urzeczywistnieniem potrzeby sprawczej kontroli nad przedstawicielami w organach władzy samorządowej.

${ }^{49}$ Obwieszczenie Państwowej Komisji Wyborczej z dnia 23 XI 2014 r. o zbiorczych wynikach wyborów wójtów, burmistrzów i prezydentów miast na obszarze kraju, przeprowadzonych w dniu 16 XI 2014, http://pkw.gov.pl/g2/oryginal/2014_11/faaecad0d74d79f247fe0b6a65e195b1.pdf (dostęp: 29 V 2016).

${ }^{50}$ Rozstrzygnięcie nadzorcze Wojewody Wrocławskiego z dnia 24 II 1995 r., ON.II.0914/5/95. 
Rozważania nad sprawowaniem funkcji kontrolnej przez rady gmin i samych radnych dopełnić może przedmiotowe stanowisko rządu w tej sprawie wyrażone przez Ministerstwo Administracji i Cyfryzacji 31 lipca 2012 r.:

[...] Rada gminy sprawuje funkcję kontrolną w granicach określonych przepisami prawa i za pomoca środków przewidzianych $w$ tych przepisach. Dla realizacji funkcji kontrolnej rada gminy przede wszystkim powołuje komisję rewizyjną (vide art. 18a ww. ustawy o samorządzie gminnym). Istotnym pozostaje spostrzeżenie, że komisja rewizyjna nie jest organem kontrolnym, a jedynie aparatem pomocniczym rady gminy; tym samym zakres działań komisji rewizyjnej uwarunkowany będzie zakresem kompetencji rady gminy (a to wskazuje przywoływany art. 18a ust. 1). W zakresie tej funkcji radzie gminy przysługują także inne instrumenty, jak np. uprawnienie przyjmowania sprawozdań z działalności wójta gminy (vide art. 18 ust. 2 pkt 2 ww. ustawy o samorządzie gminnym), rozpatrywania sprawozdania z wykonania budżetu i udzielenie bądź nieudzielanie absolutorium z tego tytułu (vide art. 18 ust. 2 pkt 4 ww. ustawy o samorządzie gminnym), zatwierdzania przepisów porządkowych wydanych przez wójta w przypadkach niecierpiących zwłoki (vide art. 41 ust. 2 i 3 ww. ustawy o samorządzie gminnym). W tym też miejscu należy zaznaczyć, że przypisany radzie gminy zakres konkretnych uprawnień jest uwarunkowany określoną ustrojowo funkcją kontrolną; rada gminy nie jest organem nadzoru, który ma prawo nakładać obowiązek określonego działania bądź zaniechania (vide rozstrzygnięcie nadzorcze wojewody świętokrzyskiego z dnia 12 października 2009 r., znak: PNK.I-0911/161/09). Nie można zapominać, iż rada gminy nie jest jedynym organem, który może kontrolować działanie wójta i służb mu podległych, wskazać można na regionalne izby obrachunkowe czy Najwyższą Izbę Kontroli $[\ldots]^{51}$.

Ministerstwo przedstawiło więc stanowisko, że rada gminy funkcję kontrolną sprawować może jedynie na podstawie norm wynikających z przepisów prawa. Należy zauważyć, że radny gminy pełni określoną funkcję nie tylko w organie gminy, ale też w gminie rozumianej jako wspólnota, społeczność lokalna. Radny gminy jest zatem nie tylko członkiem organu przedstawicielskiego, ale przede wszystkim pełni funkcję społeczną. Jego działalność to nie tylko normatywnie określone prawa i obowiązki, ale też konkretne oczekiwania ze strony mieszkańców na gruncie funkcjonowania społeczności lokalnej.

${ }^{51}$ Odpowiedź podsekretarza stanu w Ministerstwie Administracji i Cyfryzacji na interpelację $\mathrm{nr} 6277 \mathrm{w}$ sprawie uprawnień kontrolnych rad gmin z 31 VII $2012 \mathrm{r}$., http:// www.sejm.gov.pl/sejm7.nsf/InterpelacjaTresc.xsp?key=049B5C9C (dostęp: 29 V 2016). 
Władza, poza jawnymi i demokratycznie wybranymi organami wła$\mathrm{dzy}$, a także zgodnie z prawem stanowionymi mechanizmami władzy, sprawowana jest również w sposób nieformalny. Nieformalny wpływ na władzę mają różnego rodzaju grupy interesu, czyli zespoły jednostek połączonych więzami wspólnych interesów lub korzyści, których członkowie mają świadomość istnienia tych więzów. Grupy te oddziałują nie tylko na organy władzy, ale również na opinię publiczna, a przez to wpływają na polityczne rozstrzygnięcia często przy aprobacie społecznej. Grupy interesu, zwane również grupami nacisku lub podmiotami wpływu, ze względu na kryterium struktury i siły wpływu można podzielić na:

- grupy niestrukturyzowane - będące krótkotrwałym wyrazem zbiorowych emocji negatywnych;

- grupy niezrzeszeniowe - posiadające słabą organizację, bądź nawet jej całkowity brak, i działające w sposób jednorazowy, epizodyczny;

- grupy instytucjonalne - dobrze zorganizowane i zdolne do wywierania wpływu na organy władzy, np. Kościoły, przedsiębiorstwa, biurokracja;

- grupy zrzeszeniowe - powołane specjalnie w celu realizacji i promowania interesu swoich członków, np. organizacje i stowarzyszenia.

Jeśli przyjąć klasyfikacyjne kryterium celu, badacze wyróżniają: grupy interesu, których celem jest interes sektorowy, a także grupy interesu, których członków nie łączą wspólne interesy, tylko postawa wobec pewnych problemów. Ponadto wyróżnia się grupy wewnętrzne - znajdujące się w głównym nurcie procesu decyzyjnego, a także zewnętrzne - będące poza głównym nurtem tego procesu. Konstrukcję pojęciową grup interesu dopełnia podział na organizacje non profit oraz profesjonalne podmioty komercyjne, takie jak doradcy czy konsultanci. Dzisiaj działalność grup interesu uznawana jest za oczywisty składnik życia publicznego. Grupy te są powiązane z organami władzy w sposób legalny lub nielegalny: legalnie - poprzez włączanie przedstawicieli grup interesu w proces decyzyjny lub poprzez zlecanie zadań organizacjom - np. w zakresie kultury fizycznej i sportu w danej gminie. Grupy nacisku oficjalnie wypierają się związków z władzą. W praktyce jednak wywierają stały wpływ poprzez lobbing czy świadczenie usług ${ }^{52}$.

${ }^{52} \mathrm{~J}$. Blicharz, Administracja publiczna i społeczeństwo obywatelskie w państwie prawa, Wrocław 2012, s. 113-130. 


\section{Podsumowanie}

Prawidłowe i dobrze funkcjonujące społeczności lokalne opierają się na aktywnych strukturach obywatelskich, ze szczególnym uwzględnieniem trzeciego sektora. Uwarunkowania i rozwój lokalnego społeczeństwa, jako oparte na czynnikach takich jak zaufanie oraz współdziałanie, zależą od rozwoju kapitału lokalnego ${ }^{53}$. Badawcze oraz pojęciowe kategorie obywatelskości czy społeczeństwa obywatelskiego są o tyle istotne, że przez badaczy okresu PRL właściwie nie były stosowane. Naukowcy zajmowali się tymi aspektami w sposób fragmentaryczny, badając osobno: społeczności lokalne, środowiska młodzieżowe, ruchy społeczne, aktywność społeczną czy organizację obywatelską ${ }^{54}$. Nie dotyczy to tylko polskich badaczy. Trend ten, jak wskazuje D. Robertson, obejmował ogólny brak zainteresowania społeczeństwem obywatelskim w ostatnich dekadach, co spowodowane było sprowadzeniem badań nad państwem do badań systemu politycznego, a także zacieranie różnic w badaniach nad aktywnością społeczną i polityczną ${ }^{55}$. Dziś jednak badacze zaczynają coraz powszechniej pochylać się nad problematyką społeczeństwa obywatelskiego. P. Gliński wymienia również cztery podstawowe obszary przejawiania się samoorganizacji obywatelskiej, które należy badać, tj.: samorząd terytorialny, ruchy i organizacje nieformalne, partie polityczne oraz organizacje pozarządowe ${ }^{56}$. Katalog ten, jak się wydaje, zamyka zbiór czynników budujących społeczeństwo obywatelskie, którego funkcjonowanie będzie zatem wyznacznikiem stanu demokracji lokalnej, którą na poziomie polskiej gminy należy badać, aby poznać nie tylko problemy, ale również szanse rozwoju aktywności obywatelskiej, wyrażanej chociażby w obywatelskiej inicjatywie uchwałodawczej.

Badanie stanu demokracji w polskich gminach nie jest łatwe, gdyż panują w nich różne warunki. Dotyczy to zarówno różnic kulturowych, demograficznych, jak i innych. Poszczególne gminy różnią się dobrobytem, kultura, ale także stopniem zasiedzenia. Kwestie tożsamości regionalnej i lokalnej, patriotyzmu lokalnego, stopnia religijności, poparcia

${ }^{53}$ B. Lewenstein, M. Theiss, Kapitał społeczny, lokalne społeczeństwo obywatelskie, aktywizacja; zachodnie koncepcje, polskie doświadczenia, w: Społeczeństwo obywatelskie. Między ideq a praktyka, pod red. A. Kościańskiego, W. Misztala, Warszawa 2008, s. 109-110.

${ }^{54}$ P. Gliński, Przedmowa: o miejscu problematyki społeczeństwa obywatelskiego w socjologii polskiej, w: Społeczeństwo obywatelskie..., s. 9.

${ }^{55}$ D. Robertson, Stownik polityki, Warszawa 2009, s. 410.

${ }^{56}$ P. Gliński, Bariery samoorganizacji obywatelskiej, w: Niepokoje polskie, pod red. H. Domańskiego, A. Ostrowskiej, A. Rycharda, Warszawa 2004, s. 227-228. 
dla nowoczesności i zmian są inne dla gmin położonych w różnych częściach naszego kraju. Organizowane w różnych warunkach badania prowadzone muszą być ostrożnie, aby nie stać się badaniami porównawczymi. Naturalnym ograniczeniem czasowym są lata 1990-2016, co wynika wprost z przemian ustrojowych w Polsce, których jednym z głównych elementów była decentralizacja władzy i powstanie samorządów. W ciągu tych 26 lat samorządy gmin ewoluowały i zmieniały się zarówno pod względem funkcjonalnym, jak i formalnoprawnym. Pamiętać jednak należy, że obywatelska inicjatywa uchwałodawcza to konkretny akt osadzony w konkretnej rzeczywistości - na danym etapie rozwoju samorządu i na danym etapie rozwoju partycypacji obywatelskiej w danym samorządzie. Dlatego też należy zbadać, w jaki sposób rozwój lub regres samorządności rozumianej w dwóch aspektach - demokracji lokalnej oraz budowy wspólnoty w poszczególnych jednostkach - ma wpływ: po pierwsze, na konkretną wspólnotę lokalną oraz po drugie, na występowanie obywatelskiej inicjatywy uchwałodawczej. Pomocne mogłyby się okazać badania historyczno-prawne dotyczące procesów wprowadzania prawa obywatelskiej inicjatywy uchwałodawczej w poszczególnych jednostkach, gdyż mogłyby pokazać korelacje między procesem demokratyzacji, rozwojem społeczności lokalnych, a wreszcie wspominaną partycypacją sensu largo.

Przedstawiona w niniejszym tekście próba analizy stanu polskiej demokracji lokalnej nie jest optymistyczna. W społecznym funkcjonowaniu samorządu występuje wiele dysfunkcji, których przepisy prawa nie leczą. Deficyt demokracji oraz zanik funkcji kontrolnej to tylko niektóre z nich. Poza nimi wyszczególnić należy nieprawidłowy przebieg partycypacji obywatelskiej. Niewyedukowani w jej zakresie przedstawiciele działający w organach władzy gminnej nie potrafią jej odpowiednio wspierać. Preferowane przez samorządowców sposoby zarządzania gminą są sprzeczne z postrzeganym przez nich zainteresowaniem i zaangażowaniem mieszkańców w życie publiczne. Uczestnictwo Polaków w życiu publicznym nie jest powszechne. Niezależnie od tego, czy praktykowanie partycypacji wymaga dużego czy też niewielkiego zaangażowania, mieszkańcy stosunkowo rzadko włączają się w procesy decyzyjne w gminach. Im bardziej uczestnictwo to jest wymagające pod względem czasu bądź zaangażowania, tym poziom partycypacji jest niższy ${ }^{57}$. Ukazuje to, że nie

${ }^{57}$ E. Bogacz-Wojtanowska, A. Olech, M. Koziarek, Zielona ksiega wsparcia partycypacji publicznej w Polsce. Propozycje wypracowane przez Partnerstwo realizujace projekt "Decydujmy razem, Warszawa 2013, s. 10-12. 
tylko ze strony aparatu władzy samorządowej, ale również na gruncie poczucia wspólnoty i realizacji wspólnotowych potrzeb podmiotowych występują dysfunkcje. Brak poczucia wspólnoty, a co za tym idzie, błędny model rozwoju demokracji (demokracja budowana w gminach poprzez odgórne jej narzucenie, a nie oddolne podmiotowe sprawstwo) wpływa na całokształt źle funkcjonującego samorządu. Propozycją wyjścia jest pogłębienie procesów demokratyzacji i dzięki temu budowanie wspólnot. Mechanizmem, który jednocześnie doprowadziłby do rozwoju obu tych czynników, mogłaby być obywatelska inicjatywa uchwałodawcza. $Z$ jednej strony jest ona doskonałym narzędziem demokracji bezpośredniej, z drugiej zaś oddziałuje na poczucie wspólnoty poprzez wpływ sprawczy na lokalne organy władzy. Rozwój mechanizmów związanych z obywatelską inicjatywą uchwałodawczą doprowadzi więc do poprawy stanu demokracji lokalnej na poziomie polskich gmin.

\section{CITIZENS INITIATIVE IN LOCAL LAW-MAKING IN THE CONTEXT OF THE CONDITION OF POLISH SELF-GOVERNMENT AT THE 'GMINA' LEVEL}

\section{Sum mary}

The article aims to show the interdisciplinary character of citizens initiative. In the introductory part a definition of citizens initiative is given. The subsequent parts of the article prove its multi-aspect character. First, a citizen is defined as a subject authorised by law as well as the society to initiate local laws. Next a sociological and legal analysis of the mechanisms of citizens participation at the gmina (county) level is made. Participation is seen as a practical expression of the subjectivity of a citizen. The following are then analysed: social consultations, participatory budget, local referendum and a local budget which is also regarded as a form of participation. The next part describes citizens legislative initiative as a form of participation. It shows its position, reasons for its emergence and its consequences at the local level. After that there is an attempt to present in a model way the extent to which local communities have developed in Poland. It pinpoints the current problems and shows how they can be solved. In the next part mechanisms of local bodies are presented. Problems related to, among other things, local elections turnout, reducing supervision and control function, and the formation of local interest groups exercising continuous and concealed pressure on local bodies, thus influencing local laws. The conclusion of the article is that the condition of Polish democracy at a local level is not an easy research topic and the gminas have failed to develop communities of inhabitants that would pursue common interests. Individual citizens alienate themselves and care of own interests only, and this has an impact on local bodies and local law as well.

Keywords: participation - initiative - community - citizen - democracy 